\title{
Second Report on the Excavations at Stonehenge
}

\author{
By Lt.-Col. W. Hawley, F.S.A.
}

[Read 23rd June I92 I]

WHEN I presented my Report last year, work was about to begin upon some stones on the north-east of the outer circle of Stonehenge. These formed a group of four monoliths, numbered from west to east, 29, 30, $\mathrm{r}$, and 2 . They carried lintels, survivors of the series which once capped the stones of the outer circle. Nos. I and 2 had moved out of position, leaning badly outwards, and had drawn with them the three lintels from their seatings to the danger of these and themselves. They would have fallen long ago had they not been supported by props which were beginning to decay, so it was necessary to attend to them at once.

Before work could be begun the lintels had to be removed, and when they had received their timber cradles they were lowered to the ground on the 15 th June in a most satisfactory manner by the staff of the Office of Works, the operation only occupying an hour or two.

During the work the lintels were distinguished by letters A, B, and $\mathrm{c}$ from west to east. Lintel $\mathrm{A}$ rested between stones 29 and 30. Lintel в was over 30 and $\mathrm{I}$, and $\mathrm{c}$ over $\mathrm{I}$ and 2. Lintel A and the top of stone 29 were much weathered, but the other two had more or less escaped, and when lifted off revealed fine tooling by the ancient masons and showed the care taken in getting a level surface and exact fitting. The same was observable on the dowels of the stones and on the cups in the lintels to receive the dowels.

Not content with the security given by the dowels alone, the top of the stone had been chipped to leave elevated edges at the sides, so that the lintel rested in a shallow flat recess. Such careful fitting must have been done after the stones were erected; this could not have been effected unless the stones were worked in conjunction with one another, and even suggests that the lintel was slung so that it could be frequently tried until a sufficient degree of exactness had been arrived at. The same care in fitting was observable in the toggle joints which were somewhat weathered, but still fitted with sufficient accuracy to make it difficult to return the lintels to their former places. 
The timber work and other preparations having been completed, work on the stones was begun on the 28 th June, and the method of procedure was much the same as that explained in last year's Report. We used the registering frame, placing it around an area of $23 \mathrm{ft}$. by $\mathrm{I} 8 \mathrm{ft}$. including the stones $\mathrm{I}$ and 30 , and small areas were worked inside the larger one, distinguished by the letters including them.

On this occasion we stripped the turf and humus from off the whole of the large area before beginning the smaller ones and proceeding to deeper levels, so that objects in it could not drop down and become confused with things in the lower layers. Considering the extent of the upper layer the objects found were few in comparison with those at nos. 6 and 7 stones. There were the ubiquitous stone-chips : of these we had 398 of sarsen and $2,06 \mathrm{I}$ of foreign stones, the proportion of 5 to $\mathrm{I}$ (or a little more) being the same as observed before. Also there were 363 pieces of quartzite hammerstone. I might explain that the term hammerstone was given to them because they had evidently been collected for that purpose, though not actually used. It is a very hard variety of sarsen and occurs as water-worn nodules and small boulders all over Salisbury Plain especially in river valleys.

Bronze Age pottery fragments were in excess of those of the Roman period. There were sixty-two of the former and twelve of the latter, all in fragments crushed to sizes rarely greater than an inch and giving no information beyond the Bronze Age being the earliest period presented in the layer. There were five Georgian copper coins and a farthing of Charles II, an iron strikea-light, and an iron knife of about the seventeenth century.

Three pieces of human skull were met with and one tooth. These occurred at a high level with no sign of burial, and might have been the remains of some criminal hanged there and left unburied, the few pieces finding their way into the ground. They were the only human remains found, but there were several fragments of animal bones which have been kept and tabulated.

Much of the upper layer was composed of finely crushed flint which was first met with on the west side of no. I stone, increasing and becoming deeper on the outside of no. 30 , and farther west it showed a depth of from I 5 in. to 24 in. and seemed to spread towards the interior of the circle of Stonehenge.

It is possible that the builders may have laid down rough flints to afford a firm foundation when moving the large stones, which may have crushed them. On the other hand, as there are no big flints embedded in the soil below, it would seem that the material was deposited in a state of flint gravel which would 
have been necessary on account of the disturbed and muddy state of the ground whilst the work was going on. In this instance there were no objects in it, but later it was found to contain stone chips. The lower layers around both stones were of earthy chalk rubble with a few flints which formed the filling of the craters in which the stones stood. Finds in them were very few so I give the layers collectively ; they are preserved and tabulated, as are all the others, according to their position and datum. They consisted chiefly of mauls, of which there were 36 of all sizes, varying from some quite small to others of i $\mathrm{llb}$., $30 \mathrm{lb}$., and $43 \mathrm{lb}$. The latter is the biggest yet met with and is a nicely rounded specimen. It was found at the north-east corner of no. 30 stone, $5^{\mathrm{I}}$ in. below datum, and had been used as a packing-stone. The larger mauls were of very hard sarsen, and many of the smaller were of quartzite of a brown colour.

Two deer-horn picks were found in a broken state, one at a high level in front of stone 30 at 36 in. below datum line and the other to the north-east of the foot of no. I stone at 80 in. below datum. There were sixteen flint implements of a rough description, two flint hammers, ten roughly chipped flints, three flint scrapers, one borer, and two fabricators. A few fragments of foreign stone were met with which had crept down with the humus at the side of the stone and one was found amongst the rubble at 38 in. below datum line. No. I stone was the first to be excavated (fig. I). This stone was peculiar and interesting, for there was no incline from the outside for bringing the stone up to its position. The crater in the solid chalk was reached at only 29 in. below datum line. It was very regular in form with sharp inside edge, the sides showing a steep, but not perpendicular descent.

It is difficult to say how the stone could have been set in the crater. Had it been tipped in, the chalk at the side would have been crushed, and indeed the whole crater might have been ruined. Had a timber platform been placed round the edge the weight of so large a stone might have displaced and crushed it. The stone is very regular in shape, the south side being practically a straight face and the north side is much the same, but a little undercut below ground level, so that it is well suited for insertion, but how this was accomplished is a question for consideration. It is hardly credible that so heavy a weight could have been slung and lowered. Wood was more likely to have been used than raw-hide ropes, but as both are perishable we cannot know if or how they were used. This stone was not very pointed, but it tapered sufficiently to help its adjustment.

The chalk rock at the bottom of the crater was of a naturally 
crumbling description and was found to extend in this state some distance around when the pit for concrete was made. This might have been the cause of the stone shifting its position.

Forty-eight packing-blocks were found distributed around the

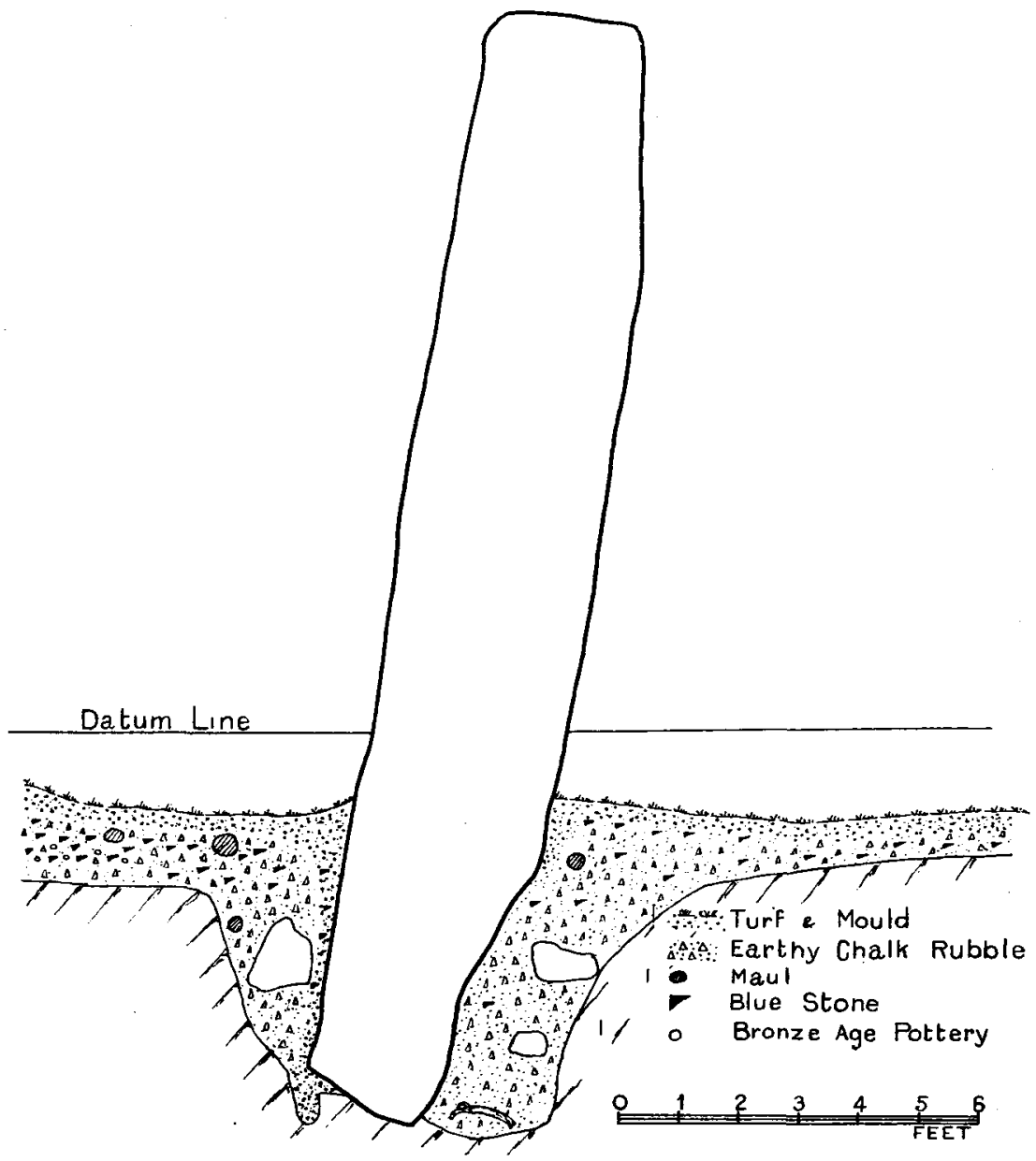

FIG. I. Section through stone no. 1.

base, the greater number placed about the north-east face and north corner. They were mostly of sarsen, but about one-third were of glauconite and Chilmark ragstone. There was a posthole on the south side of the base, not very well defined but sufficiently marked to assume that it was one, especially since it contained the substance of decayed wood. 
No. 30 stone was next taken in hand (fig. 2). The lower layers were similar to those about no. I and were in earthy chalk rubble. When this was removed and the stone laid bare to the base, a crack, previously visible I 9 in. above ground level, was now seen

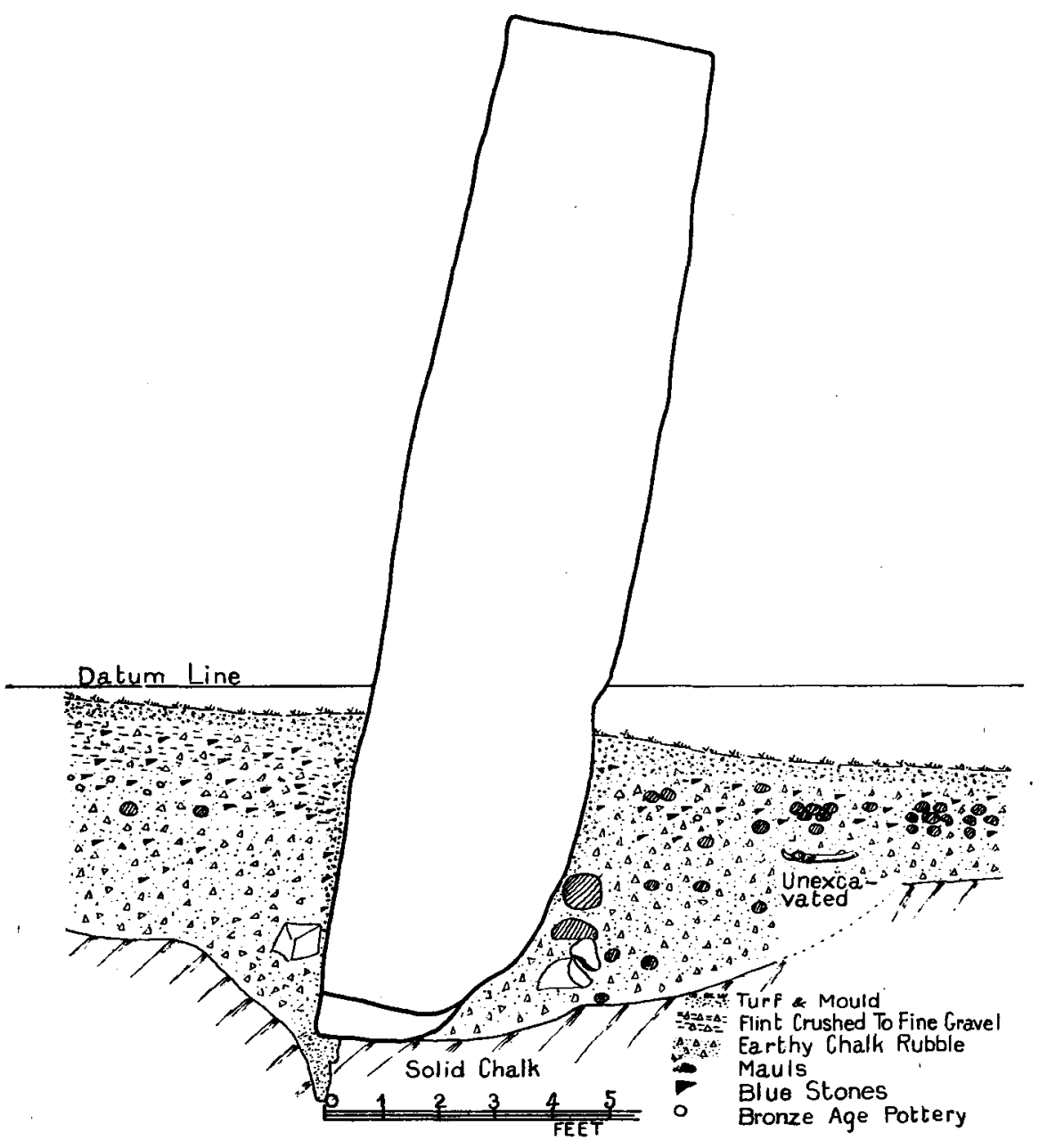

FIG. 2. Section through stone no. 30 .

to extend in a downward curve to the centre of the base on the south side and to be $6 \frac{1}{2} \mathrm{ft}$. in length. There was also a smaller crack on the west of the base which might have been caused by hammering the base of the stone to get the desired shape. This crack took a downward curve towards the centre for about $2 \frac{1}{2} \mathrm{ft}$., but in neither case was it possible to ascertain how far into the 
stone the cracks extended. The one on the east side appeared to be natural and to have existed when the stone was erected. Apparently it caused anxiety to the builders, for they seemed to

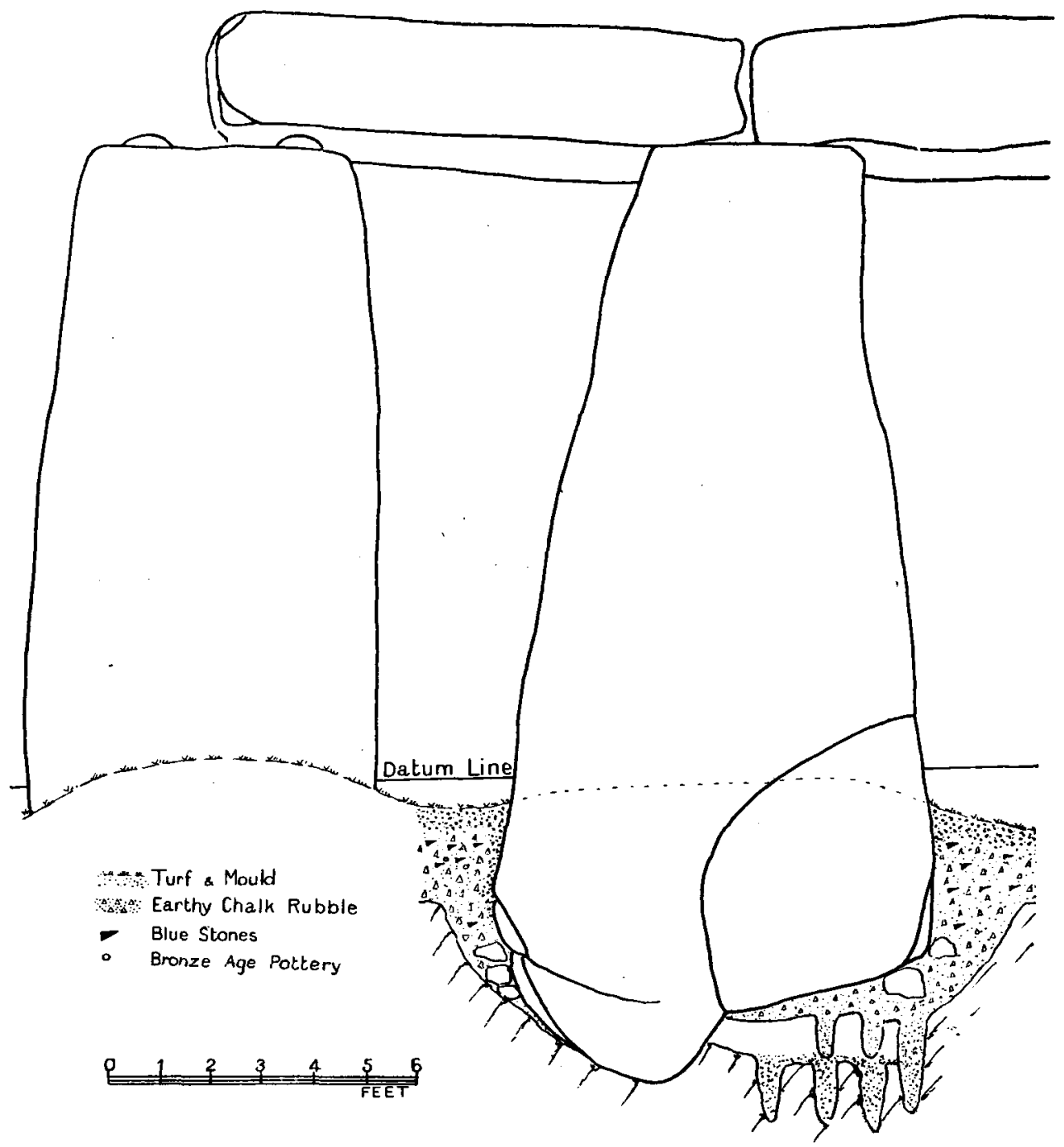

F1G. 3. Stones nos. 29 and 30.

have placed posts or perhaps wooden baulks under the curve to take the weight of the cracked portion (fig. 3). The holes for these posts were found and also those of a row of posts outside them, evidently to support the inner ones. There seemed to have been nine outer posts, but they were not well defined, as they ran one 
into another from being placed close together. One hole descended 20 in. and others from I 5 in. to I 8 in., and they all contained the brown matter of decayed wood. The same precautions had not been taken with the other crack : nor were they necessary, as the west side of the base rested in a bowl-shaped depression, pressing the cracked end against the stone, These cracks, no doubt, caused the builders to abstain from trimming the base of the stone, leaving it heavy and cumbersome and adding greatly to its weight.

As a temporary measure baulks of timber were placed under the curve, as the builders had done long ago, but shortly afterwards all danger was averted by fixing two steel cables crossed round the base, binding the cracked portions tightly to the stone by means of screw bolts at the ends of the cables, and these remained on the stone when it was finally buried in concrete. The cracks were marked during the work but showed no sign of movement.

This stone must have shifted its position considerably on the west and north, as the humus had dropped down to the lower packing-stones.

The packing-stones around the base were very numerous: there were fifty-eight of them chiefly of glauconite and Chilmark ragstone, a few only being of sarsen. The employment of these mixed stones seems to point to sarsen being unavailable, except the pieces knocked off when forming the bases and tops of the stones; consequently stone had to be searched for and brought from distant places.

When quite exposed the base of this stone was found to be 75 in. from datum line. Two steel cables were passed under both stones and secured to their cradles, preventing them slipping down. They were then jacked slightly off the ground and brought to an upright position. A long rectangular pit was dug in the solid chalk to include them to a depth which left their ends 15 in. from the bottom. A foundation of reinforced concrete was put in until it nearly reached the stones, leaving room for an iron plate. This concrete was firmly set by the 2 Ist August when the rectifying of the position of the stones was carried out. It was a long and tedious process, but by the 23 rd a very good fit was made of lintels $B$ and $c$. Lintel $\mathbf{c}$ was then taken down and B left over I and 30 stones. A bed of concrete was now put around both and when firmly set, the cradles and all supporting structures were removed and a scaffolding erected to aid in getting the final adjustment of the lintels. This was attempted on the 3 Ist August but when lintel A was tried it could not be seated in its proper position. Evidently stone 29 had moved and the 
only thing to be done was to treat it like the others, as the movement might continue and give future trouble.

\section{Diabase Stones}

When excavating stones nos. I and 30 the disturbed area came very close to two of the foreign stones of the inner circle (nos. 31 and 49). Fearing that their stability might have been weakened, it was decided to put a concrete support about their bases on the north side, bringing it to a foot below ground level.

The depth of stone 31 below the surface is $46 \mathrm{in}$. and its total height $9 \mathrm{ft} .4$ in. No. 49 is 46 in. below ground and its total height $9 \mathrm{ft} .10 \mathrm{in} .$, datum line and ground level here being identical.

No. 3 I has a curved or convex face on the north side down to the base and the edges of the sides are rounded off. No. 49 appears to have been a naturally very flat slab and retains the original brown crust on the face. The west side has been chopped away to make it narrower, or perhaps straight. There is a broken fragment 19 in. long at the base, still fitting against the stone, showing the original width there to have been 47 in. This fragment not having moved from its position seems to indicate that the stone may have been dressed after being set upright : there were, however, but few chips present, although many were found near by in the excavated area.

In the earthy chalk rubble about stone 49 , to datum 27 in., were 3 sarsen fragments, 2 quartzite, 28 of for eign stone, a piece of a sarsen maul, a rough flint implement, and a flint flake: there were no other objects below this depth. Below the earthy rubble the stone stood in a shallow hole in the solid chalk with a little yellowish marl around it. The soil around stone 3 I was similar, and contained 2 sarsen fragments, I of quartzite, 3 of foreign stone, and 3 slightly worked flints, and the bedding of the stone was similar to that of the other: there were no packing-stones in either case.

\section{STONE 29}

The excavation of stone no. 29 was begun on the 6th October in an area $\mathrm{I} 2 \mathrm{ft}$. by $9 \mathrm{ft}$. included within the registering frame. Datum line and surface level were nearly identical. All the upper surface was removed as before and consisted mainly of the crushed flint previously mentioned. Below it was earthy chalk rubble to datum 19 in. or $20 \mathrm{in}$. where solid chalk was met with except at the crater in which the stone stood. There was a considerable number of stone chips both in the crushed flint and in 
the thin layer of chalky rubble under it and, below this, solid chalk was met with at about $2 \mathrm{ft}$. below datum line. Besides the stone chips there were 5 pieces of Bronze Age pottery and 2 of Romano-British, 2 flint implements, 9 roughly chipped flints, 2 small sarsen mauls, and a broken one. The earthy chalk rubble was continued down the crater, forming packing matter amongst the blocks, and at the bottom was about a foot of white chalk rubble.

This stone proved to be the shortest yet met with, the base being only 55 in. below datum line. It had the same peculiarity as no. I in having no inclined plane starting from outside to bring it into position. The edges of the crater were found $2 \mathrm{ft}$. below ground, having sharp edges and resembling that of no. $I$ in nearly every way. The packing-stones were met with very early, appearing when the turf was removed. There were forty-seven, and these were presumably numerous on account of the shortness of the stone. Two of them were very large flints, 19 were sarsen, and the remainder of Chilmark and Hurdcot ragstone. They were distributed all round the stone but were more numerous on the north side and north-east corner. Here, a number of them, occupying a width of $4 \mathrm{ft}$., was cemented together in a hard mass which gave much trouble in extricating them. The blocks were continuous from the top of the crater to the base of the stone but only the intermediate ones were cemented. At first it was believed that the builders had intentionally used cement, especially as this was a short stone and the outer side is always the weakest. A specimen was sent to the Office of Works and an analysis was made of it, but no proof was found that cement had been used. This and other considerations point to its being natural. Small patches of it had been noticed before, for instance at no. 6 stone, also in other places where it would have been of no utility, but wherever it occurred ragstone was present, and this being a limestone may be the cause. It may happen in this way. Organic matter on the surface would create carbonic acid in the soil below : rain-water percolating downwards would take up the carbonic acid which would dissolve some of the lime of the ragstone, forming a solution of carbonate of lime, which being diffused amongst the earthy chalk would set it hard and give the appearance of concrete.

Along the outside of the base of the stone on the south side there were post holes in the solid chalk. They began at the east corner and were arranged along the south face for about $2 \frac{1}{2} \mathrm{ft}$. They were seven in number: one of them was oblong and about 8 in. wide, perhaps for a flat baulk of wood; the others varied 
in diameter from 4 in. to $7 \frac{1}{2} \mathrm{in}$. The arrangement of them much resembled those of stone 30 and contained the light substance of decayed wood. In addition to these, twenty of the packingblocks were on the south side.

The stone ended in a bluntly-pointed base with the under sides sloping inwards and meeting about the vertical axis. The solid chalk sides at the bottom of the crater seem to have been cut to coincide with the slopes of the base. There were a great many natural cavities about the base, one being a hole penetrating 15 in.

The stone was secured with steel cables to the cradle like the others (pl. VII), and the pit for concrete about it formed a continuation of the long pit the others stood in. On the 2oth October the stone was jacked up and the concrete foundation put in. This was firmly set by the I6th November, when lintel A was adjusted and fitted quite well. The concrete bed was put in and when that had set the stone was stripped and stood free (fig. 4).

The work, however, was not yet finished, as it was decided to give support to no. 2 stone in case the excavation of its neighbour might have weakened it. The stone had been from the beginning of the work strongly secured and propped, but now additional support was given. It was not necessary to move the stone, so the work was performed differently from the others. Pits were sunk to the base at the four corners of the stone, each including half a face and half a side. The pits were concreted in succession and the entire concrete bed so formed joined that of the other stones, forming a long solid bed.

The area excavated here was $\mathrm{I} 2 \mathrm{ft}$. by io ft. The stone was wider and thicker than the others and the longest yet met with, the datum depth being $84 \frac{1}{2}$ in. It had been brought into position by an inclined plane from outside. The loose soil was excavated in the pits in three layers : the first was in flinty and earthy chalk rubble, the second in earthy chalk rubble, and the third in white chalk rubble, and humus had descended at the sides of the stone. The finds were very few and, in addition to stone chips, consisted of 10 roughly chipped flints, I piece of Bronze Age pottery, Io of Romano-British, 3 of medieval with green glaze, I oyster shell (datum 37), I 2 sarsen mauls, mostly small but there was a large one weighing $35 \mathrm{lb}$. Near the bottom the stone stood in a hole in solid chalk 25 in. deep. The stone being so deep in the ground hardly required packing-blocks : there were ten small blocks of sarsen, probably only used for steadying the stone whilst it was being adjusted. 
The concreting was finished on the I $4^{\text {th }}$ November and set firmly by the 6th December, when the stone was stripped (fig. 5 ). All the lintels were finally adjusted and the work was completed. It was in every way most satisfactory, and Sir Frank Baines and his staff may indeed be proud of their work, which has surpassed all that could be anticipated.

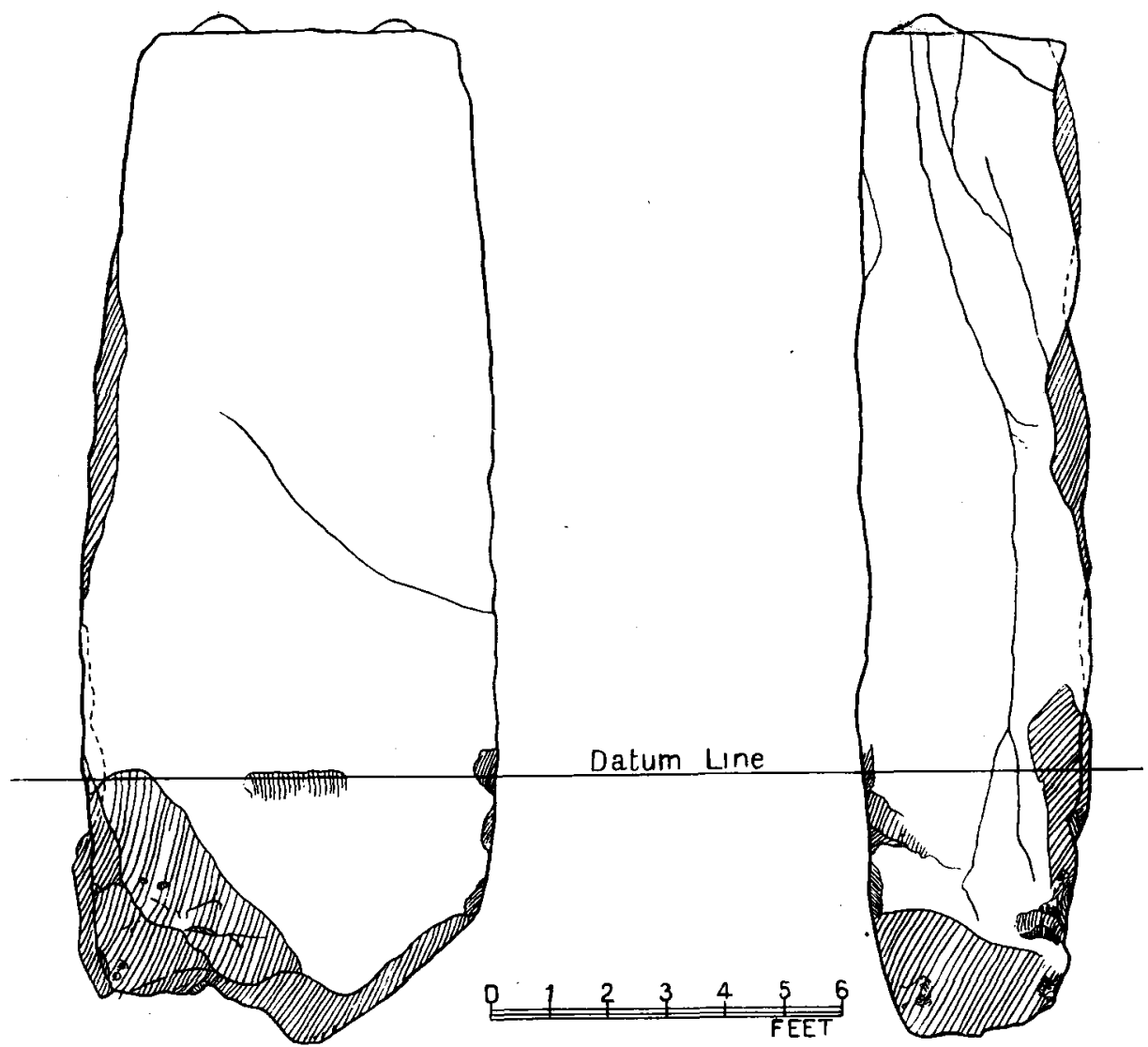

FIG. 4. Stone no. 29, after adjustment: S. and E. elevations.

\section{Aubrey Holes-Barrow Ditch}

In my last Report I said we had excavated twenty-three Aubrey holes and that they were at regular intervals with the exception of one. I am now able to state that all of them are regular both in interval and line of circle. We were misled by coming upon a hole not far from the right one, but it did not resemble the others, being rough and irregular, and perhaps made 
by a former excavator. Not being satisfied, I searched and found the other in its right place. Its dimensions are : depth 39 in., maximum diameter 38 in., and minimum diameter 57 in. In the humus over the hole were 7 sarsen chips, I I of foreign stone,

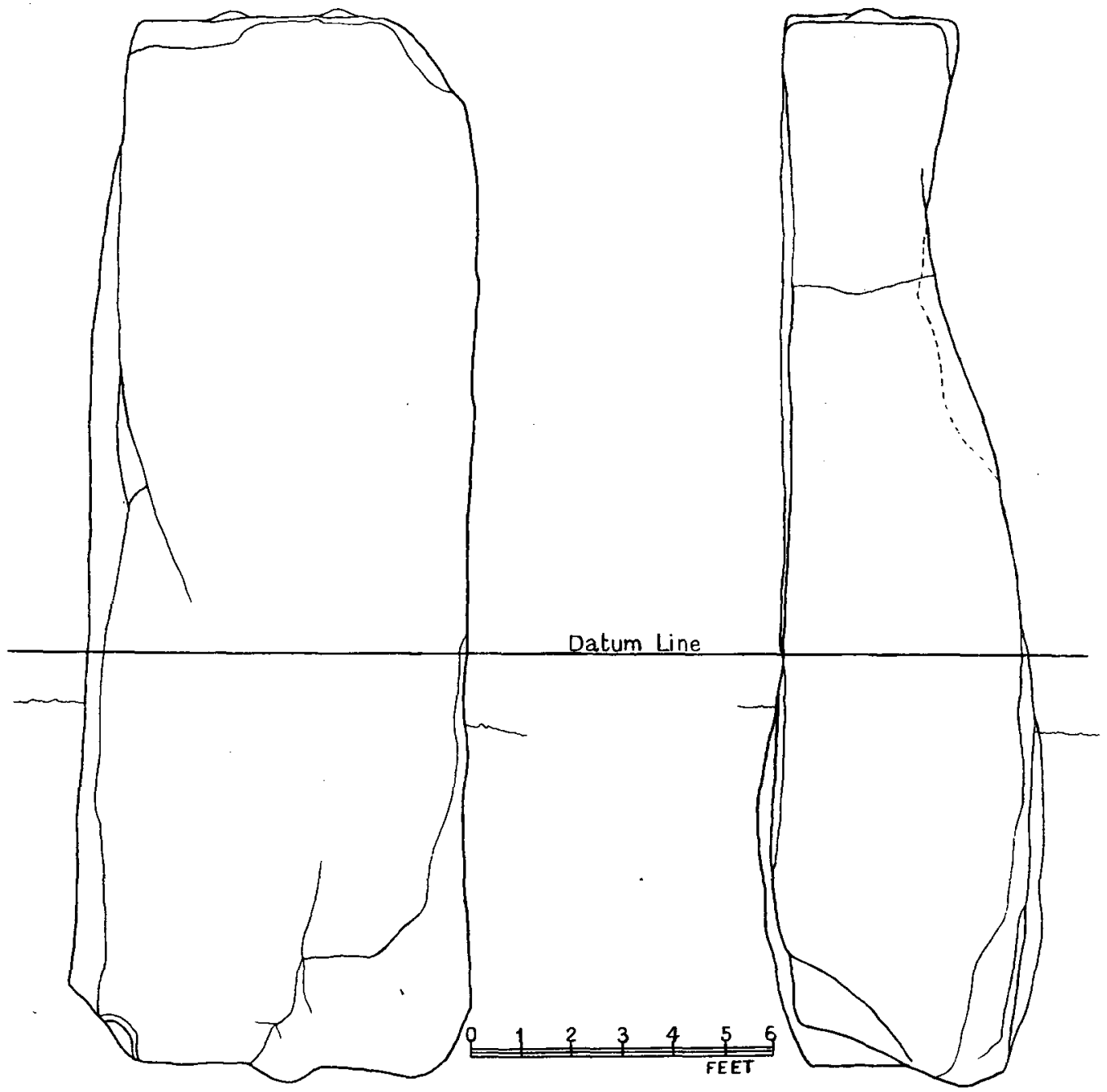

FIG. 5. Stone no. 2, after adjustment: S.W. and S.E. elevations.

5 of quartzite, I animal bone, and 2 roughly worked flints. Below the top of the hole but quite high up in it were 6 pieces of sarsen, 8 of quartzite, I 4 of foreign stone, and 2 flint flakes. There was a cremation at the side of the hole, diffused downwards from $19 \mathrm{in.}$ to $30 \mathrm{in}$. below ground level. 
The Aubrey holes opened last year have been filled in and the position of each is marked by a patch of white chalk on the surface corresponding with the size of the hole below.

The excavation about the Slaughter Stone was also filled in. We were not able to find traces of holes for the stones marked by Aubrey in his plan.

In August a small investigation of the South Barrow was made. A line was taken from the centre of Stonehenge to a peg on the rampart for a base line which ran contiguous to the Barrow ditch. The radius of the Barrow was found to be $26 \mathrm{ft}$., the centre being about $2 \mathrm{ft}$. from the cavity left by ain earlier excavator. Three sections were opened side by side, each of $\mathrm{I} 2 \mathrm{ft}$. by $6 \mathrm{ft}$. crossing the ditch and taking in a portion of the Barrow. The small ditch is shallow and of irregular depth, being $3 \mathrm{I}$ in. deep where we began on the north-east, becoming less at the end of the third section where it was $20 \mathrm{in}$. It reached the rampart here and one cannot say yet if it continued. I am waiting until I have worked along the rampart ditch so as to get a view of it to see if it is continued through the bank. The soil of the small ditch was dark earthy rubble above and chalk rubble below, with many fallen flints. In the dark rubble there was a piece of sarsen, the only object the ditch afforded. The Barrow soil is very shallow over the chalk rock, the curve of it from the ditch making it appear higher than it really is. The soil is of earthy chalk rubble with humus and turf over it, and the three combined do not exceed 14 in., except at an Aubrey hole, three of which are covered by the Barrow.

The objects found in the rubble and humus of the three sections were I 2 sarsen chips, 7 of quartzite, I 27 of foreign stone, 7 chipped flints, 5 rough flint cores, I animal bone fragment, I piece of Bronze Age pottery, 5 of Romano-British, I flint flake, and 2 scrapers. In section 2 there was a piece of the edge of a finely polished axe-head. At the time the Barrow was made the site of the Aubrey hole must have appeared as a shallow depression which became filled with the rubble of the Barrow. The Aubrey hole was excavated and found to be similar to the others and had the inner edge crushed down. The depth of it is $3 \mathrm{ft}$. with an equal diameter of $2 \mathrm{ft} .5 \mathrm{in}$. In the rubble covering the top were I piece of sarsen, 3 of quartzite, and I I of foreign stone. Lower down were the remains of a cremation 9 in. above the bottom. At the top where the edge was crushed was a small depression containing a few cremated bones. The excavation gives the impression that this site was one of a hut rather than a barrow. 


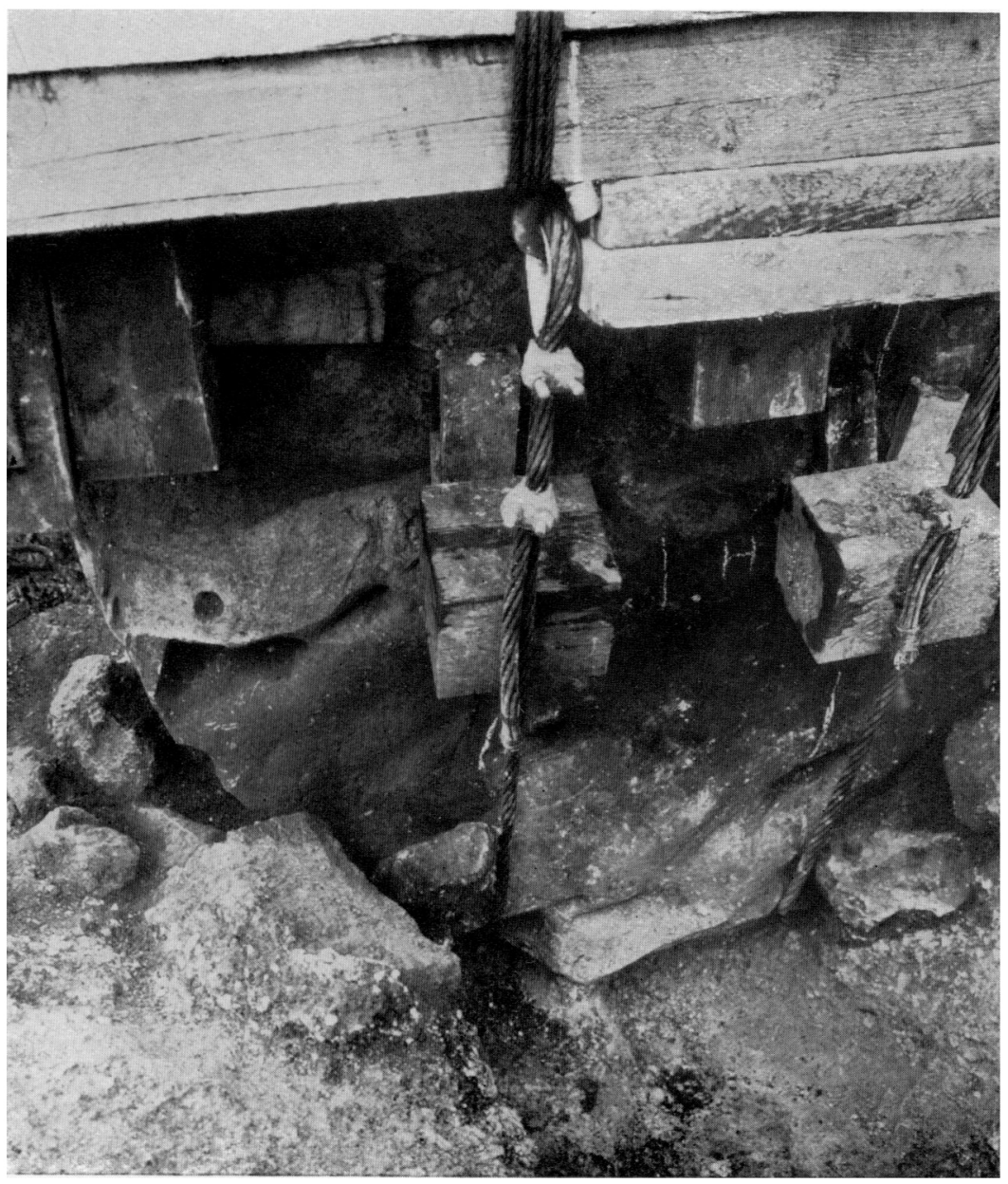

Stone No. 29, showing Packing-Blocks in Position 

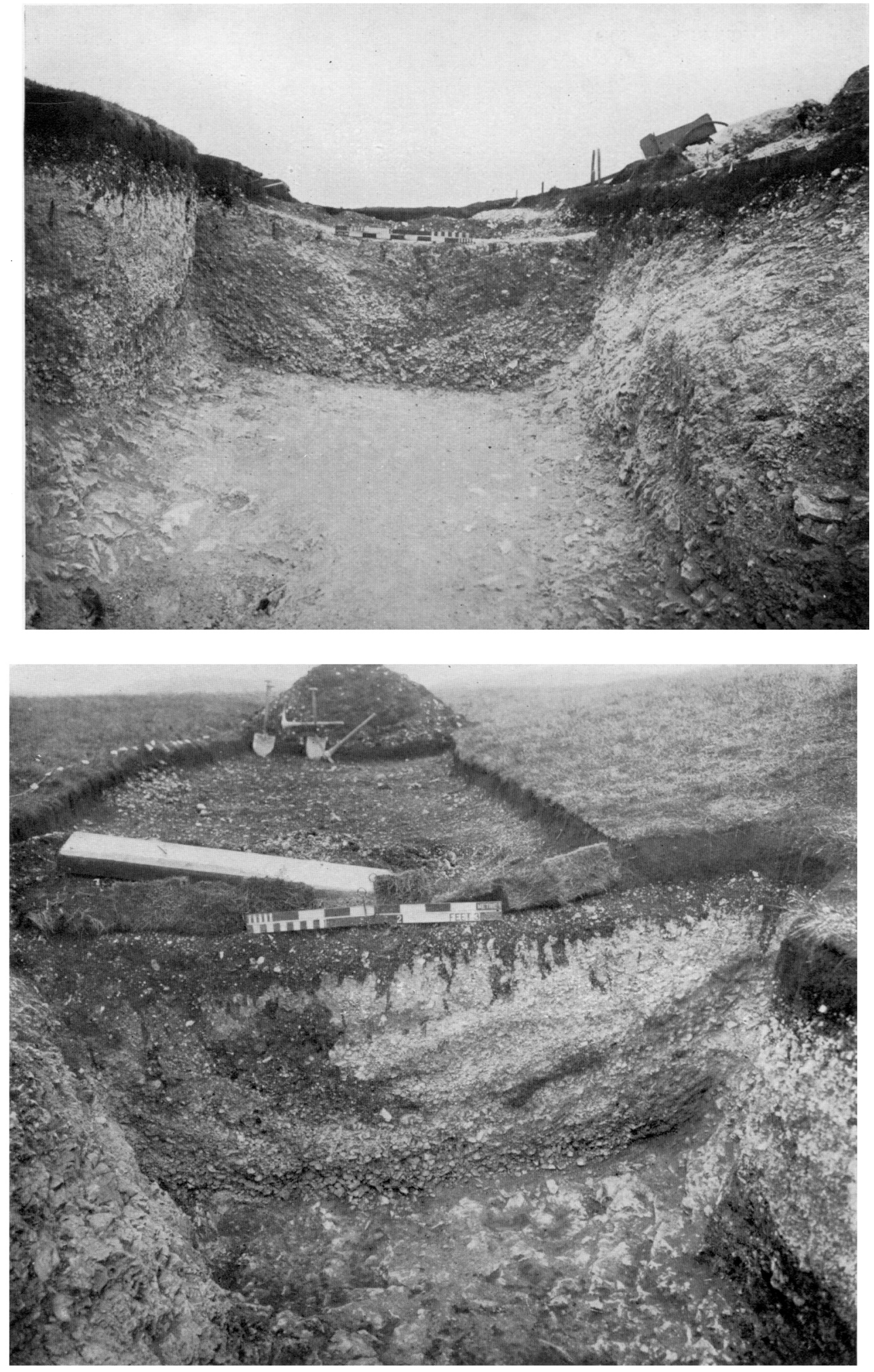

FIG. 2. Section through Ditch, looking West 
I have also to mention two excavations of the Rampart Ditch. The first (pl. VIII, fig. I) was madelast autumn and is a continuation westward of the one reported last year and of the same dimensions as that one, viz. $2 \mathrm{ft}$. by $10 \mathrm{ft}$. This was worked in downward layers. The top layer was in humus followed by earthy chalk rubble to a depth of I 4 in. to $20 \mathrm{in}$, and was deeper near the counterscarp side. In it were $r 5$ pieces of sarsen, 9 of quartzite, 57 of foreign stone, 24 small fragments of Bronze Age pottery, 6 of RomanoBritish, I piece of deer-horn, and several bone fragments. This layer ended upon a very compact bed of yellowish silt with a few flints in it. Objects of the sort found in the previous layer were completely absent. At 35 in. below ground-level there was a cremation. The bones in it were not numerous. They were very white and had been deposited in a roughly made recess in the soil. The next layer was in loose chalky rubble which continued to the bottom. A collection of wood ashes mixed with chalk occurred but was without burnt bones.

Nine fragments of animal bone and a stag-horn tine were also found. The bottom presented a fairly level line, being about 53 in. to 54 in. below ground-level.

The rise of the chalk on the escarp side was regular, but that on the counterscarp not so. From it a projection of solid chalk protruded ; beyond it to the west the ditch widened again.

The second excavation (pl. VIll, fig. 2) was a continuation of the last. It was $26 \mathrm{ft}$. long by $9 \mathrm{ft}$. wide. After removing the top layer of humus and earthy chalk rubble I excavated it in a different manner from the last, as the curved layers are not suitable for vertical excavation. Vertical layers were removed from top to bottom, each layer being a foot thick, so that in advancing, a section of the ditch was always presented to view. If a cremation was come upon, the state of the strata would show if it had been placed there at the time or after the silting.

The excavation differed in appearance from the preceding ones. The centre line of the bottom varied from 52 in. to $6_{3}$ in. below ground-level. The side of the escarp was fairly regular except at the extreme end where it penetrated a foot into the side, making the bottom of the ditch wider. The counterscarp was more irregular than in the last excavation, and had a similar bulging projection followed by a recess like the last. The projections extend about $3 \mathrm{ft}$. The recesses between are curved in the bank, and the floor of the ditch in front of them is level and smooth, giving the idea that the recesses might have been used as habitations opening into one another through the narrow part caused by the projection. Three feet in front of the projection 
last found there is a hole in the chalk at the bottom, $20 \mathrm{in.} \mathrm{deep}$ and from $22 \mathrm{in}$. to $27 \mathrm{in}$. wide. The end of the hole is more pointed than bowl-shaped and the chalk wall of the escarp descends into it. There was nothing in it beyond loose white chalk. A great many roughly chipped flints were met with, mostly at the centre line on the bottom, but were distributed everywhere more or less upon the bottom; also patches of flint chips and fine flint débris, some being embedded in a thin layer of mud as if trodden in when the ditch was wet. A few flint cores were found, but only one definite flint implement, which was a borer.

The upper layer of humus and chalk rubble was about $2 \mathrm{ft}$. thick and contained objects of a similar character and period to those of the last excavation, their presence terminating abruptly where the rubble layer met the marly silt below it. I shall not enumerate them all, but amongst them was a stag's horn tine, an oyster shell, and a small metal fragment of two thin plates of bronze riveted together, probably Romano-British. There were three sarsen mauls. One was a fine one of about $30 \mathrm{lb}$., the next was smaller and rougher, and the third quite a small one. The large one had sunk through the rubble and was embedded slightly in the silt. The silted marl did not produce anything and objects were not found until near and on the bottom, where they consisted of chipped flints, 6 broken stag's horn picks, 3 pieces of antlers, apparently cut off when making picks, and Io smaller fragments of horn, 37 pieces of animal bone, including part of the jawbone of a pig, and two leg-bones of the same. A large fragment of the horn core of a large bovine animal, having the appearance of a bison, was found about ${ }_{5} \mathrm{in}$. above the bottom, and close to it a roughly rounded piece of chalk showing signs of cutting. There was no sign of any fire having been made on the ditch floor, and in all of the three excavations there was no sign of pottery after the top layer joined the silt.

The excavations so far appear to indicate two distinct periods and that the ditch and rampart were made at a time considerably anterior to Stonehenge, for the silting would have taken long to accumulate. When the ditch began to be neglected the lower silting would take place quickly by reason of frost attacking the chalk sides, as can be seen by the fallen white chalk over the ditch floor. This would go on until the fallen chalk had covered the chalk rock of the sides and so stopped further frosting. Silting would then become slower and the pace would be very slow at last, when only a little was deposited by rain flowing down the rampart. When Stonehenge was built the movement of the numerous big stones and of many people, and the general disturbed 
state of the ground, brought the earthy chalk rubble layer over the silt. Objects of that period became mixed with it and deposited as we have found them. Later, in a quieter time, humus and turf were formed, and objects of subsequent periods have passed through the surface as we see it at present.

\section{DISCUSSION}

Bishop Browne remarked that whereas the Pictish stones often bore engravings of various kinds, there was nothing of the sort to temper the austerity of Stonehenge, which was unapproached in interest by any monument in the island. He recalled the report made to King Alfred about the Esthonians, who enacted that every one must be cremated, and provided heavy penalties for leaving the smallest piece of bone unconsumed. Such was evidently not the case at Stonehenge. The builders of that monument belonged to a race not hitherto traced : they were not of Mediterranean origin, and must be identified among later peoples.

Rev. G. H. ENGLEHEART was struck with the painstaking accuracy displayed in the present as in the preceding report, and cornmended Colonel Hawley's caution in drawing conclusions, which contrasted favourably with two articles recently published in a daily newspaper, and only surpassed by the leading article suggested by them. Perhaps further misapprehension might be avoided by a preliminary account of the year's work at Stonehenge being drawn up by the competent authority and communicated to the press. The ditch had been described as earlier than the monument : were the ditch and rampart made before even the outer ring of blue stones was erected ?

Mr. REGINALD SMITH pointed out that if nothing of the megalithic period (the main date of Stonehenge) was found on or near the bottom of the ditch, it was clear that the rampart and ditch preceded even the ring of Prescelly stones presumably erected in the Aubrey holes. Hence the first construction on the site resembled the enclosure of a disc-shaped barrow. Flint implements and flakes had been mentioned in association with Bronze Age pottery: were all the flints therefore of the Bronze Age, or were some of the sherds neolithic? Oyster shells had also been noticed, the occurrence of which low in the ditches of certain earthworks of the South Downs had recently been taken as proof of Roman date. Colonel Hawley was evidently prepared to make a special study of the ditch round the barrow in order to decide whether the barrow was earlier or later than the rampart of Stonehenge.

Mr. DALE said there was nothing but the Bronze Age pottery to disturb the conclusion reached in I9OI that Stonehenge was erected 3,800 years ago. It was important to ascertain whether the pottery was contemporary with the monument or had worked down from the 
surface. He hoped the Society would publish a reproduction of Aubrey's map of the missing stcnes.

Mr. BUSHE-Fox had visited Stonehenge several times during the year and had been much impressed with Colonel Hawley's perseverance and absorption in the work. Few excavators would be ready to live in all weathers isolated in a hut on Salisbury Plain. He was present when one of the lintels was raised and was interested to see how accurately the mortise and tenon fitted. To obtain such precision the stones must have been finished in position; and how the necessary mechanism was provided constituted one of the many problems of Stonehenge. If there had been interconnected dwellings in the ditch, a considerable deposit of refuse might have been expected. Was the filling merely the result of silting, or had earth been purposely thrown into the ditch?

Mr. TAPP was primarily interested in the geological side of the problem, and had been able to secure a report on the foreign stones from Dr. Thomas. Many museums had been visited, and a parallel investigation of the stones at Carnac in Brittany was in contemplation. The removal of such stones from Pembrokeshire presented no great difficulty, as they would have come most of the way by water, via Bradford-on-Avon.

Rear-Admiral SOMERVILLE was interested in the orientation of Stonehenge, but did not go so far as the late Sir Norman Lockyer. To make accurate calculations with such stones was impossible, and the older stones there were not even faced. In addition to mauls and flint hammers the masons of Stonehenge must have had something in the nature of a chisel. A great trench was the first monument on the site, and very few stone circles surrounded with a ditch were known: there was one in the south of Ireland. It would be of interest to note the bearings of the gaps noticed in the side of the ditch, as the general orientation implied a knowledge of astronomy and might reveal the nationality of the builders.

Colonel HAWLEY replied that the antler was almost the only object found at the bottom of the ditch, the horn-core being $I_{4}$ in. or $1_{5}$ in. higher. There was a rounded piece of chalk showing signs of cutting, and the borer was the only flint implement. The cutting-edge of a finely-polished stone axe came from the top of the barrow.

The Chairman (Mr. C. L. Kingsford, V.-P.) assured Colonel Hawley that his zeal and self-sacrifice were highly appreciated by the Society: and thought that a report in the Society's Fournal would be preferable to a preliminary notice in the daily press. 